\author{
〔84〕高分子電解質の拡散 \\ 第 1 報 グリオキシル酸による部分アセタール化ポリビニル \\ アルコールと水の系における拡散 \\ (1959 年 2 月 5 日受理)
}

細野正夫*·桜田一郎**

\begin{abstract}
要旨 グリオキシル酸により部分アセタール化したポリビニルアルコール(K 塩)と水の系に抽る 拡散実験を行ない, 次の結果を得た。i）抎散定数はカルボキシル基含有率(モル\%)があまり大きくないときに は、これにほほ比例して増大する。ii) 重合度の影慗はあまり認められない。iii)この系の拡散現象は Fickの 第 1 法則によりほほ記述することができ，iv）極限粘度数より推定した摩擦抵抗と，抎散定数とより求めた試 料のカルボキシル基結合数は分析值とよく一致する。v) 対イオンの固定は取り报われたカルボキシル基含有 率の筑囲では無視して良い。
\end{abstract}

1. 緒言

拡散は化学的ポテンシャルの差によって生じる力のた めに, 分散質が分散媒中に移動する現象として記述する ことができる。この現象は分散質, 分散媒が単一で，化 学結合のような特別な作用がなく, 2 成分系として取り 扱いらるような場合には, 簡単に

$$
J=-m \Gamma \mu=-D_{\nabla} n
$$

によって解析することができる。ここに $J$ : 単位時間 に単位面を通って流れる分散質の量(単に流束と呼ぶこ とにする), $\mu$ : 化学的ポテンシャル, $m:$ 摩擦抵抗に関 する係数, $n$ : 単位体積中の分散質の数, $D$ : 拡散係数 (極限希薄瀑度におけるものを拡散定数と特に呼ぶこと にする)である。(1)式で後の表現は Fick の第 1 法則に ほかならない。しかし電解質(高分子電解質も含めて)の ように溶媒(たとえば水)中でいくつかの正負イオンに解 離するよ5な場合には, 素朴的に(1)式を許容するわけ にはゆかないだろら。たとえイオンの移動によって生じ るイオンふんい気の非対称性による减速効果 (緩和効果, Relaxation effect), イオンふんい気が形成されているこ とに基く流体力学的な障害一一電気泳動効果 (Electrophoretic effect) を無視したとしても。それは系が多成 分采であることに原因する。各分散犋が独立で相互に作 用がない場合には, 各成分の流束は(1)式で記述するこ とができ，全流量はその算術和として表現することがで きる(普通の高分子物質の分子量分配を拡散法によって 求めらるのはこの理由による)。しかし一般的には Lamm $^{1)}$, Qusager ${ }^{2)} ら に よ り$ 取り扱われたよ5に, 各成 分は相互に作用しあい，1つの成分の化学的ポテンシャ ルの勾配は他の成分の拡散にも影響するという視野に立

* 京都大学化学研究所 (大阪府高㚘市古曾部)

** 京都大学工学部㵶維化学教室 (京都市左京区吉田本町)
つ必要があろう。このような場合には，もはや Fick の 第 1 法則は成立しない。電解質の拡散は一般にこれに対 応したものであるよらに考えられる゙,。しかし他方， 電解質の拡散現象は各種正負イオンの数に対応するだけ の自由度を持つわけではない。Gibbs-Duhem の関係式 による制限を受けるばかりでなく，また電気的中性の条 件も満足せねばならない。挔散の過程においては, 起り らる数多くの対応の仕方でその条件を満足しらるという 不確定さは残るけれども。この条件はもし一一本報で取 り扱ったよ5に一一正, 負の 2 種のイオンと水(溶媒)の 系のみよりなる電解質の拡散に問題を限定するならば, 上に述べたよらな解析を複雑にする諸因子からわれわれ を解放するだろう。

1 個の高分子イオンと解離によって生したた個の対 オンとより成る高分子電解質の水中への拡散を考える。 個々のイオンは, 単独ではその容積から考えて抎散速度 は非常に異なることが予想される。しかし電気的中性の 条件から 2 つのイオンの拡散速度は同じでなければなら ない。したがって，この場合にはそのような速度で拡散 する 1 種類の分散質を考えれば良いことになる。よって Fick の第 1 法則が適用しらる。初めQusager, Fuoss ${ }^{5)}$ により得られた普通の電解貎の拡散に関する式はこのよ らな場合に相応する。いま問題にしている高分子電解質 にこれを応用すると次式が成立するものと考えられる。

$$
D=\frac{k T(1+\nu)}{\rho_{p}+\nu \rho_{K}}\left(1+\frac{\partial \ln \gamma \pm}{\partial \ln c}\right)
$$

ここに $\rho_{p}, \rho_{K}$ はそれぞれ高分子イオン, 対イオンの摩 擦係数, $\gamma \pm$ はイオンの平均活量係数, $c$ は高分子電解 質のモル溇度である。(2)式はまた Katchalsky ら ${ }^{\theta)}$ が取 り扱ったように Gibbs-Duhem の関倸式によって浸透圧 係数およびその濃度依存性により表現することができる ((2) 式では電気泳動効果に対する考慮が省略されてあ 
$\left.ろ^{23)}\right)$ 。極限希薄濃度においては $\partial \ln \gamma \pm / \partial \ln c=0$ と考 えられるから (2) 式より高分子電解質のいま問題にして いる系に㧍ける拡散定数は，解離した対イオンの数 (高 分子イオンに含まれる有効な解離基数)により支配的に 決定されることがわかる。イオンの摩擦係数は粘度測定 その他により推定することができる。したがって，また 拡散の実験から有効な解離基の数一一表現を逆にして香

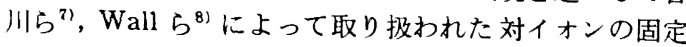
の問題を追求することができよう。

本報告は試料としてグリオキシル酸により部分アセタ ール化したポリビニルアルコールのK塩(以下 PVAGと 略記する)を選び，以上の視野の下に(2) 式を検討するこ とを目的としたものである。従来合成高分子電解質の 拉散実験の報告は少ない。それは本文の初めに述べた ような事情にも起因するのであろう。いうまでもなく本 報で取り扱った采は一般的視野から見ればかなり特殊化 されたものであるといえよう。とはいえ他の電解質が共 存するような場合の研究の第 1 段階として意義があるも のと考えられる。拡散現象は非可逆現象である。したが って (2) 式の誘道に祭しては, 拡散が化学反応過程に比 較して平衡状態からのずれが比較的少ない過程であっ て, 全体の自由エネルギーの変化は粘性力 (viscous force) により消散するエネルギーとすることができると い5よ5なことが前提されている9)。これはもちろん高 分子電解質の拡散のみの問題に限られているわけではな い。しかしこのことは, 高分子電解質の活量を拡散実験 から求めうることを一一低分子電解質については最近こ のよ5な試みが始められてきた ${ }^{10)}$ —約束するものとし て(2)式がなりたつかどらかは興味が深い。

\section{2. 試料}

ク゚リオキシル酸を分別ポリピニルアルコール(PVA) に反応させて得るアセタール化物の $\mathrm{K}$ 塩 $(\mathrm{PVAG}$ )であ る。供試試料の一部は桜田, 中岛, 石田ら ${ }^{11}$ の粘度的研 究に使用されたものである。他の一部は文献 (12) (13)に より報告された電圧滴定，電気泳動実験に供された。残 部は当教室伊勢氏の調製による。試料の重合度, 電導度 滴定より求めたカルボキシル基含有率，極限粘度数(溶 媒：水, 測定温度 $30 \pm 0.1^{\circ} \mathrm{C}$ ) 第 1 表に示す。極限粘度 数の推定は Fuoss ${ }^{14}$ の粘度式に従って求めた。この方法 により極限粘度数を求めると計算誤差がかなり伴う久点 がある。また理論的にもいくらかの難点があるよ5で ある。しかし現在のところこれにかわるべき方法のない こと,およびあとで述べる実験結果の検討においては(た とえば極限粘度数より分子末端間距離の自乗平均の平方 根などを求めるときには), その誤差は約 $1 / 3$ となるから,

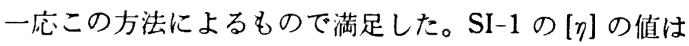
第 1 図に示した $[\eta]$ と重合度 $P$ の関倸から推定したもの
第 1 表 PVAG の重合度, カルボキシル基 含有率, 極限粘度数

\begin{tabular}{c|c|c|c}
\hline \hline 試 料 & 重合度 & $\begin{array}{c}\text { カルボキシル基 } \\
\text { 含有率(モル\%) }\end{array}$ & $\begin{array}{c}{[\eta]} \\
(\mathrm{g} / 100 \mathrm{cc})\end{array}$ \\
\hline $\mathrm{B}-0$ & 955 & 0 & 0.60 \\
$\mathrm{~B}-22$ & 955 & 0.081 & 0.68 \\
$\mathrm{~B}-1$ & 955 & 1.22 & 7.40 \\
$\mathrm{~S}-1$ & 890 & 5.73 & 36.4 \\
$\mathrm{~S}-7$ & 1700 & 5.82 & 112 \\
\hline S - 4 & 370 & 6.37 & 7.9 \\
SI- 4 & 460 & 6.68 & 13.8 \\
SI- 3 & 980 & 7.14 & 83.6 \\
SI- 1 & 2150 & 7.00 & $(230)$ \\
\hline
\end{tabular}

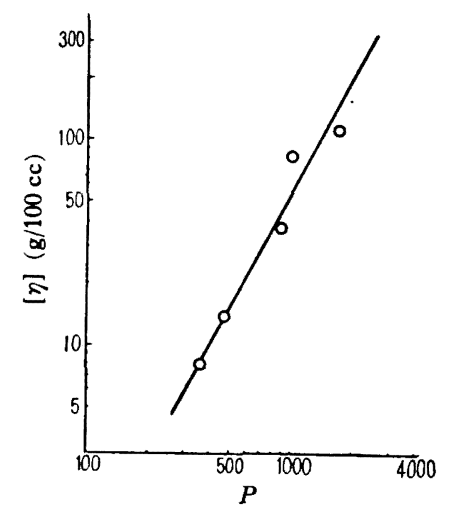

第 1 図 PVAG の $[\eta]$ と $P$ の関俰 $\left(30^{\circ} \mathrm{C}\right.$, 水 $)$ カルボキシル基含有率(モル\%):6〜7

である。第 1 図でカルボキシル基含有率が不ぞろいのた め実験点にかなりのばらつきがみられるが、この程度の

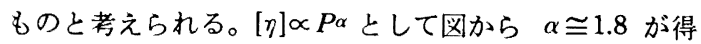
られる。これは普通の合成高分子について得られている 值と比較してかなり大きく, 真直な棒状分子に対して与 えられると考えられている值 $(\alpha=2)$ に近い。これについ ては Fuoss の粘度式の検討とともに，実験の集積を必 要とするものと思われるが,このような例はボリメタア クリル酸の $\mathrm{Na}$ 塩について Oth, Doty ${ }^{15}$ により報告され ている。重合度は原料たる分別 PVA の水溶液に対する 極限粘度数から中島, 古館ら ${ }^{16)}$ の式により求めたものを それとした。

\section{3. 拡 散 実 験}

\section{1 測定装置}

日立製シュリーレン・ダイヤゴナル円筒レンズ法によ るチゼリウスの装㯰。 


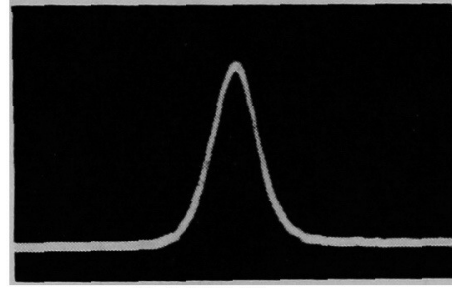

a : B-0(PVA) $c_{0}=3.09$ (1.30 days)

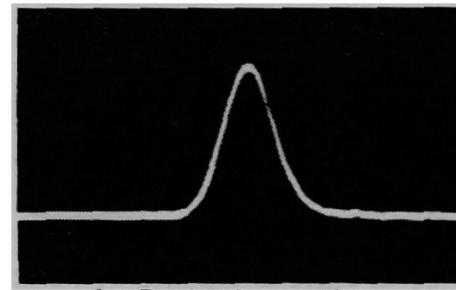

b: B-22 $(G=0.081)$

$c_{0}=2.72$ (0.992 days)

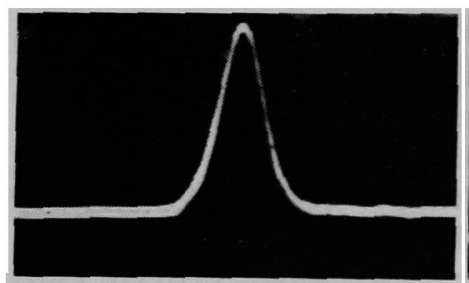

c: $\mathrm{S}-4 \quad(G=6.37)$

$c_{0}=2.62$ ( 0.1373 days)

* 分散媒として $0.329(\mathrm{~g} / 100 \mathrm{cc})$ の同じ試料水溶液を使った。 $c_{0}$ : 初濃度 $(\mathrm{g} / 100 \mathrm{cc}), G$ : カルボキシル基含有率 (モル $\%$ )

第 2 図拡散曲線写真 (左側: 溶媒水, 右側 : 溶液)

$$
D_{A W}={ }_{0} D_{A W}\left(1+k_{D} \frac{c_{0}}{2}\right)
$$

から求める。 $\left(c_{0}\right.$ : 初濃度, $k_{D}$ : 濃度依存係 数) $k_{D}\left(c_{0} / 2\right)$ は Gralen の得た結果 ${ }^{17)} よ$ り 1 に比して十分小さいとして次式より算 出し, $k_{D}\left(c_{0} / 2\right)-t^{-1}$ の図加ら $t^{-1} \rightarrow 0$ とし た $k_{D}\left(c_{0} / 2\right)_{t^{-1} \rightarrow 0}$ を求め, これを(3)式に利 用する。(その要領につけてはたとえば文 献 (18)参照)。

$$
k_{D}\left(\frac{c_{0}}{2}\right)=-\frac{m_{0} \Delta x}{2 \sigma^{2} H_{\text {nax }},} \sigma^{2}=\frac{m_{2}}{m_{0}}
$$

$H_{\max }$ : 拡散曲楾の最高の高さ, $\Delta x$ :

$H_{\text {max }}$ を与える距㒕

\section{3.2}

Beckmann, Rosenberg の方法 ${ }^{19)} に よ り$ 1 つの拡散曲線図加ら濃度 $c\left(0 \leqq c \leqq c_{0}\right)$ に対する拡散俰数 $D_{B R}$ を次式により算 出し

$$
\begin{aligned}
& D_{B R}=-\frac{1}{2 t y} \int_{-\infty}^{x} x y d x \\
& c=\frac{c_{0}}{m_{0}} \int_{-\infty}^{x} y d x
\end{aligned}
$$

$y:$ 最初の界面から $x$ なる距離におけ る拡散曲線の高さ

$D_{B R}-c$ の関係加図式的に $c \rightarrow 0$ とし た拡散定数 ${ }_{0} D_{B R}$ を求める。本実験の場合 $D_{A}, D_{W}$ を求めるときにそらであったよう に, 拡散時間が異なると $D_{B R}-c$ 図は一致 しないことが認められた。表現を変えてい えば, 異なった ${ }_{0} D_{B R}$ が与えられること

\section{2 測定条件}

イオン交換樹脂により製精した水を溶媒として使用し た。測定温度は $30 \pm 0.1^{\circ} \mathrm{C}$ であった。

\section{3 拡散係数の算出}

拡散倸数 $D_{-4}, D_{W}$ は次式により求めた。

$$
\begin{aligned}
& D_{A}=\frac{\left(m_{0} / H_{x=0}\right)^{2}}{4 \pi t} \\
& D_{W}=\frac{\left(m_{2} / m_{0}\right)^{2}}{2 t}
\end{aligned}
$$

$m_{0}$ : 拡散曲線の面積, $m_{2}$ : 抎散曲線の 2 次の能率, $H_{x=0}$ : 最初の界面の位置にお污る拡散曲線の高さ, $t:$ 拡散時間

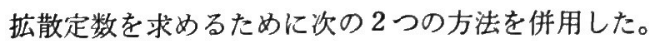

3. $3.1 D_{A}, D_{W}$ の平均値

$D_{A W}\left(=\left(D_{A}+D_{W}\right) / 2\right)$ に対し Gralen, 桜田, 細野の方 法 $^{17), 18)}$ により
になる。ところか゚ $D_{A}, D_{W}$ を算出する場合と同じ量の 拡散時間を補正すると,これらの不一致は解消した。こ の場合にも界面形成に伴ら機械的原因による若干の(界 面の) 動播 (disturbance) が拡散時間の補正を必要とし ているのであろら。

\section{4. 実 験 結 果}

\section{1 拡散曲線図}

拡散曲線写真の数例を第 2 図に示す。いずれの場合も ガウス曲線に近いなめらかな曲線であるが、いくらか溶 液側们ゆがんでいるのが認められる。

\section{$1.2 D_{B R}$ とcの関係图}

Beckmann, Rosenberg の方法によって得る $D_{B R}$ と $c / c_{0}$ の関係図の二,三の例を第 3 図 $(\mathrm{A}),(\mathrm{B}),(\mathrm{C}),(\mathrm{D})$ に示 した。図で $c / c_{0}$ の值が 0.1 以下および 0.9 以上の実験 点は誤差を考慮して省略してある。いずれの場合も $c / c_{0}$ の小さいところで $D_{B R}$ に対しほぽ直線的となっている 


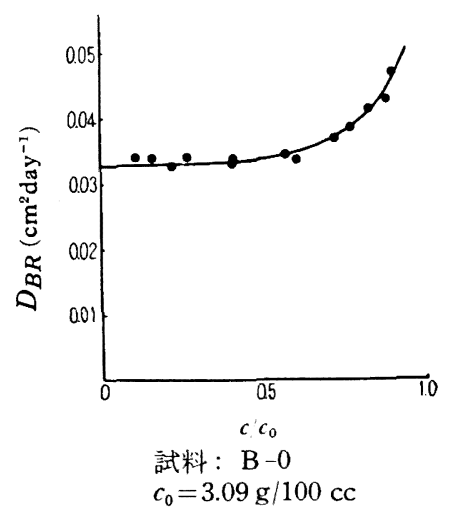

第 3 図 $(\mathbf{A}) D_{B R}-c / c_{0}$ の関倸

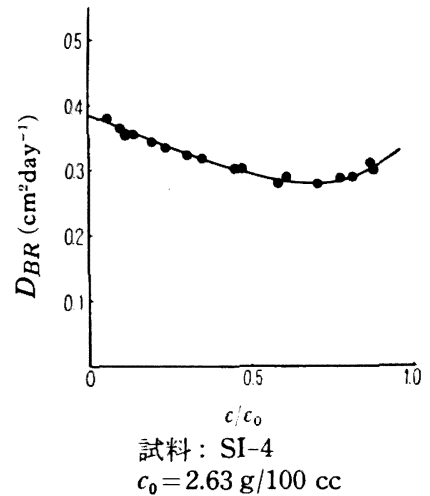

第 3 図 $(\mathbf{C}) \quad D_{B R}-c / c_{0}$ の関倸

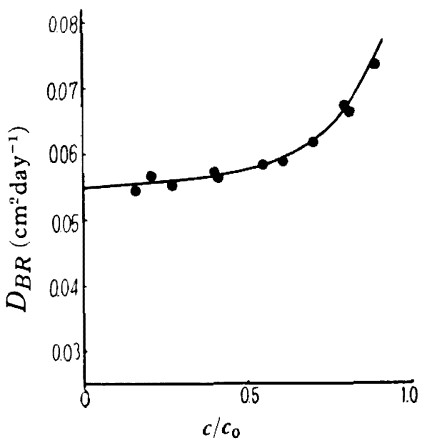

試料：B-22 $c_{0}=2.72 \mathrm{~g} / 100 \mathrm{cc}$

第 3 図 $(\mathbf{B}) \quad D_{B R}-c / c_{0}$ の関倸

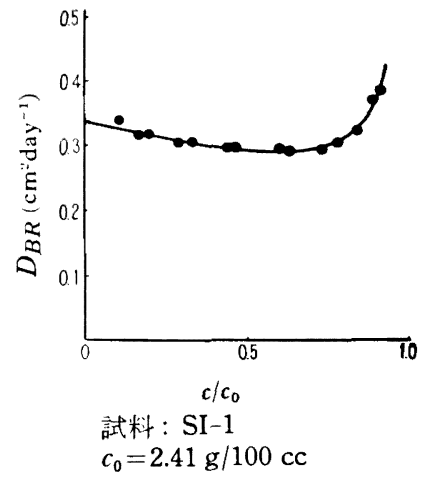

第 3 図 (D) $D_{B R}-c / c_{0}$ の関倸

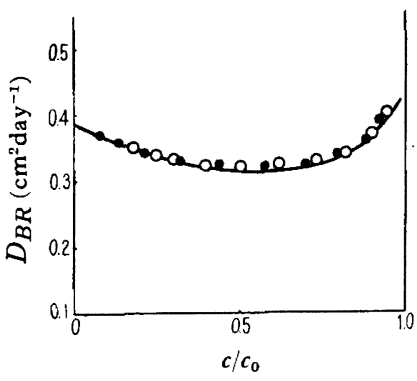

$0.329 \mathrm{~g} / 100 \mathrm{cc}$ の水溶液 - 水 試料： $S-4$ $c_{0}=2.62 \mathrm{~g} / 100 \mathrm{cc}$

第 4 図 分散媒として水および試料溶液を 使った場合の $D_{B R}-c / c_{0}$ の関係

であった。第 4 図に S-4 試料につき, 2.62 $\mathrm{g} / 100 \mathrm{cc}$ 水溶液に対し分散媒として 0.329 $\mathrm{g} / 100 \mathrm{cc}$ の同じ試料の水溶液を使った場合 と水のみの場合との比較の例を $D_{B R}-c / c_{0}$ の関係で示した。試料水溶液を分散媒に使 用した場合の $c / c_{0}$ は水の場合のそれに換算 してある。両者の図形は全く重なり合い水 の場合に対し，水溶液の場合にはちょうど その濃度から曲線が始まっていることが認 められる。実験が故障なく行なわれている ことを示すものであろう。

\section{3 拡散定数とカルボキシル基含有率 の関係}

重合度がほぼ同じで，カルボキシル基含有率が異なる 試料について行なった実験結果を第 2 表に示す。 $c / c_{0}$ が 比較的小さいところでの拡散係数の濃度依存係数 $k_{D}$ (gralén の方法によったものを $k_{D G}$, Beckmann, Rosenberg の方法によるそれを $k_{D B R}$ として)もあわせ 揭げた。 $0_{0} D_{A} A W ，{ }_{0} D_{B R}$ の平均值をとり，これを図示する と第 5 図のようである。図より明らかなようにカルボキ シル基含有率が若干大きくなると拡散定数は急激に（力 ルボキシル基含有率にほぼ比例して)増大し 7 モル\% 程

第 2 表 PVAG の拡散定数に及ぼすカルボキシル基含有率の影響

\begin{tabular}{l|cc|c|c|c|c}
\hline \hline 試 料 & 重合度 & $\begin{array}{c}\text { カルボキシル基 } \\
\text { 含有率(モル\%) }\end{array}\left({ }_{0} D_{A W}\right.$ & ${ }_{0} D_{B R}$ & $k_{D G}$ & $k_{D B R}$ \\
\hline $\mathrm{B}-0$ & 955 & 0 & 0.0314 & 0.0330 & +0.02 & +0.02 \\
$\mathrm{~B}-22$ & 955 & 0.081 & 0.0538 & 0.0550 & +0.04 & +0.02 \\
$\mathrm{~B}-1$ & 955 & 1.22 & 0.148 & 0.160 & -0.06 & -0.11 \\
$\mathrm{~S}-1$ & 890 & 5.73 & 0.349 & 0.340 & -0.08 & -0.10 \\
$\mathrm{SI}-3$ & 980 & 7.14 & 0.340 & 0.350 & -0.06 & -0.07 \\
\hline
\end{tabular}

$D: \mathrm{cm}^{2} \mathrm{day}^{-1}, k_{D}$ : 濃度の単位 $\mathrm{g} / 100 \mathrm{cc}$ 


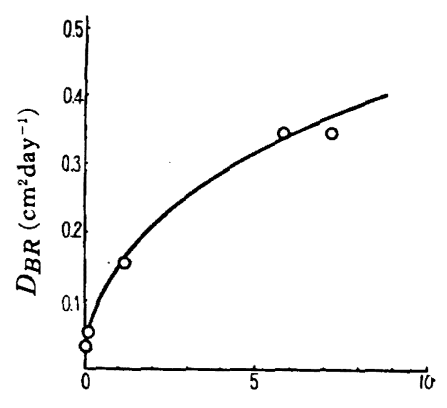

カルボキシル基含有率(モル\%)

第5図 PVAG の㹡散定数とカルボキシル基 含有率の関倸 10倍程度大きくなることがわかる。

\section{4 拡散定数と重合度の関係}

カルボキシル基含有率がほぼ同じで重合度が異なる試 料について行なった実験結果を第 3 表に示す。
度グリオキシル酸が結合すると PVA のそれに比して約

$\propto R(R:$ 高分子イオンの半径または分子末端距離の自乗

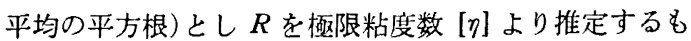
のとするとほぼ(

$$
{ }_{0} D \propto G \cdot P^{(2-\alpha) / 8}
$$

とすることができるだろら。ここに $G$ はカルボキシル 基含有率であり， $\alpha$ は $[\eta] \propto P^{\alpha}(P$ : 重合度) として得ら れる指数で, 分子の形態, 溶媒の高分子内部への透過性 あるいは分子内相互作用および溶媒分子との相互作用 に基く高分子の広がりに関するパラメーターとして理解 されているものである。したがって $\alpha$ は $G$ により影響 されるであろう。 $\alpha$ の変化をいまかりに分子の形とい5 視野から眺めてみる。Gが小さい間は鎖状高分子の溶媒 中での形は球形からのずれが比較的小さくないものと考 えることができよう。したがって $\alpha$ の変化は比較的小 さい。Gが大きくなると解雕間相互の反ぱつ力のために しだいにそのずれが大きくなり，遂には棒状に近い形を とる可能性が增大するであろう。 $\alpha$ は 2 に近つく。文献

(15)のこの部分に 関する結果は,そ の間の事情を物語 っているものと考 えられる。これを (8)式についてみ るに $G$ が比較的小 さいと $\alpha$ の変化も 小さく,したがっ て重合度が一定な

表に見られるよらに, カルボキシル基がある程度含有さ れると重合度がかなり翼なって兄(わずかにその影響が 見られるよ5にも思えるが)拡散定数にほとんど変化が 認められないことがわかる。PVA の場合にはこの程度 重合度が変ると 3 倍程度の変化がみられる20)。注目され て良い事柄であろ5。カルボキシル基含有率がさらに小 さくなってはじめて重合度の影響がみられるものと思わ れる。

\section{5. 実検結果の検討}

\section{1 却散定数とカルボキシル基含有率の闑係}

極限希薄濃度で，かつ他の塩が分散媒水中に存在しな いときは，イオンふんい気の非対称性に原因する緩和効 果, イオンふんい気の存在による電気泳動勃果を無視す ることができる ${ }^{28)}$ 。よって(2)式より拡散定数 ${ }_{0} D$ 解析 しらる式として

$$
{ }_{0} D=\frac{k T(1+\nu)}{\rho_{p}+\nu \rho_{K}}
$$

を得る。簡単のため高分子イオンによる対イオンの固定 を無視し5るものとし，さらに $\rho_{p} \gg \nu_{K}$ と考える。 $\rho_{p}$
れば ${ }_{0} D$ は $G$ にほぼ比例して増大することになる。し かし $G$ が大きくなると $\alpha$ の変化が大きくなり，この部 分加らの寄与のために $G$ の増加に対応する。 $D$ の増加は 抑制されることになろう。第 5 図に示した結果はその間 の関係を示すものと考えることができよう。Gがある程 度大きくなれば $\alpha$ はやがて一定となるだろう。そうす ると再び ${ }_{0} D$ は $G$ の增加に比例して増大することが考え られる。これは ${ }_{0} D$ と $G$ の関係図で 1 つ変曲点が存在 することを子想せしめるであろ5。さらにGが大きくな ると Wall ら の) の結果によれば対イオンの固定が増加す る。したがって再び ${ }_{0} D$ の $G$ 対応する增加はそのた

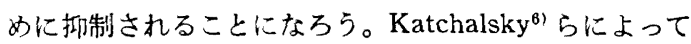
示された実験結果はこの間の事情を示寸ものとして興味 が深い。

\section{2 拡散定数と重合度の関係}

(8)式の関係からほぼ理解することができる。Gがあ る程度大きくなると $\alpha$ は 2 に近つくくもと予想される (第 1 図に示された結果では $\alpha \approx 1.8$ である)。したがっ てこの場合 $G$ が一定であれば $0 D$ の重合度 $P$ に対応す る変化は鈍威となる。第 3 表の結果はそれを示すものと 
して理解されるだろう。ただ (8) 式をいま問題としてい る視野から素朴的に許容すると $\alpha$ が 2 より小さいときは $\left(G\right.$ を一定として ${ }_{0} D$ は $P$ の増加とともに大きくなると いう理解しにくい結果を得る。さらに立ち入った考察の ためには(8)式の誘導に際してなされた省略を考慮する 必要のあることを示しているのであろう。

\section{$5.3(g)_{c \rightarrow 0}$ に対する検討}

(7)式の妥当性はいろいろの視野から検討することが 可能である。(本節 $(a)(b)$ での考察は見方を変えれば大 局的にみたその検討でもあるだろら）Katchalsky ら ${ }^{6)}$ 行なったように(2)に対し Gibbs-Duhem の関係を使い, $\partial_{\nu} / \partial c \cong 0$ として浸透圧係数 $g$ およびその濃度変化の項 によって $D$ を表現し，極限希薄濃度の場合を考えると

$$
{ }_{0} D=\frac{k T(1+\nu)}{\rho_{p}+\nu \rho_{K}}(g)_{c \rightarrow 0}
$$

が得られる。 $(g)_{c \rightarrow 0}$ は極限希薄濃度における浸透圧係数 である。(7)式との比較からもかかるよ5に $(g)_{c \rightarrow 0}=1$ で なければならない。っの值として電導度滴定より求めた 分析值をとり， $\rho_{p}$ を極限粘度数より推定することにすれ ば，抝散定数より $(g)_{c \rightarrow 0}$ が求まることになる。 $\rho_{p}$ の值 は i) Flory の関倸式より

$$
\begin{aligned}
& \rho_{p}=P \eta_{0} R, \quad R=\left\langle\bar{r}^{2}\right\rangle \pm \\
& \left.[\eta]=\Phi R^{3} M^{-1}, \quad P=5.11, \quad \Phi=2.1 \times 10^{21}\right\}(10) \\
& \left\langle\bar{r}^{2}\right\rangle: \text { 分子末端間距離の自乗平均, } M: \text { 分子量, } \eta_{0} \text { : } \\
& \text { 溶媒の粘度 }
\end{aligned}
$$

として推定することができる。これから求まる $(g)_{c \rightarrow 0}$ を $g_{F}$ とした。ii) 流体力学的に等価な球でおき換え， $r$ を その分子半径とすると Einstein の関倸式より

$$
\rho_{p}=6 \pi \eta_{0} r, \quad[\eta]=\frac{2.5}{100} \frac{3}{4} \pi r^{8} \frac{N}{M}
$$

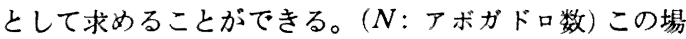
合の $(g)_{i \rightarrow 0}$ を $g_{E}$ とした。iii) 真直な棒状分子を考え, 古典的な Herzog の関係式を使らと

$$
\rho_{p}=6 \pi \eta_{0} a / \ln (2 a / b)
$$

で表現できる。(2a: 棒の長さ, $b:$ 棒の太さ)これより得 る $(g)_{c \rightarrow 0}$ を $g_{H}$ とした。第 4 表は第 $1,2,3$ 表に得られ た実験結果を利用し，以上の考えに従って求めた $(g)_{c \rightarrow 0}$ の值の比較である。

(12) 式による場合は $2 a=P \times 2.5(\AA)(P:$ 重合度) $b=$ $10(\AA)$ を選んだ。 $b$ の值は若干変っても $g_{H}$ の值はあ まり変らない。 $\rho_{K}=6 \pi \eta_{0} r_{K}$ とし $r_{K}=2.5 \AA$ を選んだ。 この值もまた若干変化しても $(g)_{c \rightarrow 0}$ の值はあまり変ら ない。第 4 表の $(g)_{c \rightarrow 0}$ に関する結果をみるに, $g_{F}$ の值 は測定された試料の範囲では(第 4 表はほぼカルボキシ ル基含有率の順に記載されている) ほぼ 1 とみなして良 いであろう。 $g_{E}$ の值はカルボキシル基含有率が大きく なると若干大きくなる傾向を持つようである。カルボキ シル基含有率が小さいとき $g_{H}$ の值は明らかに過大であ る。カルボキシル基含有率が大きくなると一応理解しう る数値となるが, やや小さい。 $g_{E}$ がカルボキシル基含有 率の大きいところで若干大きくなる傾向があるのは分子 の並進運動 (拡散) とずれ(粘度)の場合における摩擦効果 が, 分子の球形からのずれのために, 同一の流体力学的 に等価な球で固き換えることができないことを示してい るものと考えることもできよう。 $g_{H}$ がカルボキシル基 含有率の小さいところで過大となる理由は明らかであ る。カルポキシル基含有率が大きいところでやや小さく なるのは $b$ 值をかなり大きくとる必要のあることを意 味しているのかもしれない。しかしまた, 計算の不備と いうよりはむしろ Herzog の式自身の適合性が吟味され る必要があるかもしれないであろう。

以上の計算では高分子イオンによる対イオンの固定が ないものとしてょの値として電遒度滴定より求めた分析 值を使った。そこでこうした前提なしに(7)式により逆

\begin{tabular}{|c|c|c|c|c|c|c|}
\hline \multirow{2}{*}{ 試 料 } & \multirow{2}{*}{ 重合 度 } & \multirow{2}{*}{$(1+\nu)_{o b}$} & \multirow{2}{*}{$(1+\nu)_{c a l}$} & \multicolumn{3}{|c|}{$(g)_{c \rightarrow 0}$} \\
\hline & & & & $g_{F}$ & $g_{E}$ & $g_{H}$ \\
\hline B -0 & 955 & 1 & 0.83 & 0.83 & 0.98 . & 2.07 \\
\hline B -22 & 955 & 1.77 & 1.50 & 0.86 & 1.00 & 1.99 \\
\hline B - 1 & 955 & 12.65 & 10.9 & 0.87 & 1.01 & 0.93 \\
\hline$S-1$ & 890 & 52.0 & 54.8 & 1.03 & 1.16 & 0.75 \\
\hline$S-4$ & 370 & 24.6 & 27.6 & 1.08 & 1.20 & 0.78 \\
\hline $\mathrm{SI}-4$ & 460 & 31.8 & 38.1 & 1.12 & 1.31 & 0.80 \\
\hline $\mathrm{SI}-3$ & 980 & 71.0 & 75.5 & 1.04 & 1.17 & 0.75 \\
\hline $\mathrm{SI}-1$ & 2150 & 151.5 & 123 & 0.93 & 1.03 & 0.65 \\
\hline
\end{tabular}
にンを搪散定数と極限粘度数とから求めることを試み た。摩擦抵抗に関する関係は Flory の式によった。第 4 表の $(1+\nu)_{o b}$ は電導度滴定より求めた分析值を, $(1+$ 2) cal はいまの考えにより求めたものを示している。両 者の一致はかなり満足すべきものである。このことから

第 4 表 昖散定数と極限粘度数より求めた $(g)_{c \rightarrow 0}$ 
逆に本報で取り扱った程度のカルボキシル基含有率のも のでは, 対イオンの固定は実験誤差の籁囲内で無視して 良いことがわかる。これはまた Wall ら ${ }^{8)}$ の実験結果と 一致する。

\section{$5.4 D_{B R}$ とc の関係図について}

第 3 図 $(C)(D)$, 第 4 図㐳示されたものはいずれも凹型 をしている。一般に試料が不均一であるとこのような傾 向が生じるものと考えられる。しかし第 3 表の結果から もわかるようにカルポキシル基含有率がある程度大きい ものでは，少なくとも重合度に関する不均一性の影響は 緩和されるであろら。したがってアセタール化反応が均 一に行なわれているものとすれば, これらの凹型図形は (2)式からわかるように平均活量係数 $\gamma \pm$ の濃度変化々 摩擦抵抗の濃度依存性との相互関係により生じているも

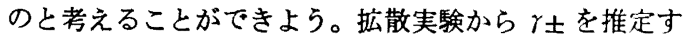
ることが可能であることになる。摩擦抵抗の濃度体存性 は超遠心法による沈降保数の測定から知ることができよ う。しかし現在のところ高分子電解質に関してこの目的 のためになされた実験報告はほとんどないようである。 非電解質高分子については Newman, Eirich ${ }^{21}$, Walls, Holde ら ${ }^{222}$ の研究があるが，その結論をそのまま高分子 電解質の場合に適用することはかなり危険であると思わ れる。本報文中では 由である。

\section{文献}

1) O. Lamm: J. Phys. Chem., 51, 1063(1947); ibid., 61, 948(1957)

2) L. Qusager: N. Y. Acad. Sci., 46, 241 (1945)

3) J.W. McBain and G.R. Dawson: J. Am. Chem. Soc., 56, 52(1934)

4) P. J. Dunlop and L. J. Gosting: ibid., 77, 5238 (1955)
5) L. Qusager and R.M. Fuoss: J. Phys. Chem., 36, 2689(1932)

6) O. Kedem and A. Katchalsky: J. Polym. Sci., 15, 321 (1955)

7) F. Ōsawa, N. Imai and I. Kagawa: J. Polym. Sci., 13, 93(1954)

8) J.R. Huizenga, P.E. Grieger and F.T. Wall : $J$. Am. Chem. Soc., 72, 2636, 4228(1950)

9) R.A. Robinson and R.H. Stokes: "Electrolyte Solution", 293(1955), Butterworths Scientific Publications, London

10) H.S. Harned : Discussion Farad. Soc., 24, 7(1957)

11) 中岛, 石田, 桜田: 高化, 14, 259(1957)

12）挼田，細野，伊勢：高化, 15, 175(1958)

13）伊勢, 細野, 桜田：高化, 15, 339(1958)

14) R.M. Fuoss and U.P. Strauss: J. Polym. Sci., 3, 246 (1948)

15) A. Oth and P. Doty: J. Phys. Chem., 56, 43 (1952)

16) 中島, 古館：高化, 6, 460(1949)

17) N. Gralen: Dissertation, Uppsala, 60 (1944)

18）桜田, 細野: 高化, 10, 85(1953)

19) C.O. Beckmann and J. Rosenberg: Ann. N.Y. Acad. Sci., 46, 329(1945)

20)細野, 桜田: 高化, 9, 64(1952)

21) S. Newman and F. Eirich: J. Coll. Sci., 5, 541 (1950)

22) M. Walls and V.H. Holde: J. Polym. Sci., 14' 81 (1954)

23）泳動効果による摩擦抵抗の增加は Qusager, Fuoss $ら^{5)}$ の式を応用すると

$$
\Delta_{\rho}=\left(\rho_{p}-\rho_{K}\right)^{2} \frac{\nu}{(1+\nu)} 6 \pi \eta_{0}(1+\kappa r)
$$

となる。(2)式の分母にこれだけの増分を加える必 要があ万5。高分子濃度 $c_{p} \rightarrow 0$ となれば $\kappa \rightarrow 0$ と なり,したがって $\Delta_{\rho \rightarrow 0}$ となる。

\title{
Diffusion of Polyelectrolyte
}

\section{Diffusion of Poly(vinyl alcohol) Partially Acetalized with Glyoxylic Acid in Water}

By Masao Hosono* and Ichiro Sakurada**

\begin{abstract}
The diffusion of poly(vinyl alchohol) partially acetalized with glyoxylic acid in salt-free aqueous solutions has been investigated. In such systems, the diffusion was found to obey Fick's first law. The diffusion constants, diffusion coefficients at zero concentration, increased proportionally to the carboxyl group contents for samples of lower degrees of acetalization, while they were almost independent of the degree of polymerization. The numbers of carboxyl groups estimated from the diffusion constant and the intrinsic viscosity were in good agreement with those obtained from electric conductometry. The fixation of counter ions by polyions was found to be negligibly small in our experiments.
\end{abstract}

* Institute for Chemical Research, Kyoto University (Takatsuki, Osaka)

** Department of Textile Chemistry, Kyoto University (Kyoto) 